\title{
Analytical Methods for Simultaneous Estimation of SGLT2 Inhibitor and DPP-4 Inhibitor in their Combination for Treatment of Type 2 Diabetes Mellitus
}

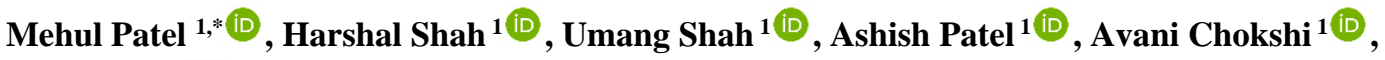 \\ Niraj Vyas ${ }^{1}$ iD \\ 1 Ramanbhai Patel College of Pharmacy, Charotar University of Science and Technology (CHARUSAT), At and Post: \\ Changa-388421, Dist. Anand, Gujarat, India \\ * Correspondence: mehulpatel.ph@charusat.ac.in;
}

Scopus Author ID 55617424500

Received: 11.08.2020; Revised: 25.09.2020; Accepted: 27.09.2020; Published: 2.10.2020

\begin{abstract}
The Saxagliptin Hydrochloride (SAXA) and Dapagliflozin (DAPA) Fixed-Dose Combination has recently been approved for the treatment of Mellitus type 2 diabetes. In order to simultaneously estimate SAXA and DAPA is a bulk product and its formulation, the study aimed at developing a simple, fast, sensitive, and validated UV-Spectrophotometric and reversed-phase highperformance liquid chromatography (RP-HPLC) methods. Simultaneous equation UV method was performed on Shimadzu UV-1800 Spectrophotometer based on measurement of SAXA and DAPA absorption in methanol at $210 \mathrm{~nm}$ and $224 \mathrm{~nm}$, respectively, over 6-22 $\mu \mathrm{g} / \mathrm{mL}$ and 12-44 $\mu \mathrm{g} / \mathrm{mL}$ linear ranges. RP-HPLC method was designed using an HPLC system-equipped PDA detector. The method has been validated for SAXA and DAPA for a range of 8 to $22 \mu \mathrm{g} / \mathrm{ml}$ and from 16 to $44 \mu \mathrm{g} / \mathrm{mL}$. In compliance with ICH guideline Q2(R1), the optimal approach is successfully validated. The results showed that the method was accurate (98.22-100.28 percent w / w and 99.48-100.15 percent w / w SAXA and DAPA, respectively) and precise (percentage of relative standard deviation < 2.0). Developed methods follow ICH Q2 (R1) criteria and sufficient to apply regulatory versatility for submission.
\end{abstract}

Keywords: saxagliptin hydrochloride; dapagliflozin; UV-spectrophotometry; Reverse-Phase HighPerformance Liquid Chromatography.

(C) 2020 by the authors. This article is an open-access article distributed under the terms and conditions of the Creative Commons Attribution (CC BY) license (https://creativecommons.org/licenses/by/4.0/).

\section{Introduction}

The combination of saxagliptin (SAXA) and dapagliflozin (DAPA) may have a major glycaemic regulation advantage without the risk of weight gain and hypoglycemia, which may be linked with other medicines used to treat diabetes of type 2. SAXA is an oral hypoglycemic (anti-diabetic) dipeptidyl peptidase-4 (DPP-4) inhibitor with a IUPAC name (1S, 3S, 5S)2[(2S)-2-(3-hydroxy-1-adamantyl)-acetyl]-2-azabicyclo[3.1.2] hexane-3-carbonitrile (Figure 1) [1]. It is used for the treatment of type II diabetes either in monotherapy or in combination with other drugs. The drug acts to suppress protein/enzyme, dipeptidyl peptidase 4 (DPP-4), competitively resulting in an increased amount of active augmentin: gastric inhibitory polypeptide (GIP) and glucagon-like peptide-1 (GLP-1). Dapagliflozin (DAPA) is a sodiumglucose co-transporter-2 inhibitor with a chemical name $(2 \mathrm{~S}, 3 \mathrm{R}, 4 \mathrm{R}, 5 \mathrm{~S}, 6 \mathrm{R})-2$-[4-chloro-3-(4- 
ethoxybenzyl) phenyl]-6-(hydroxymethyl) tetrahydro-2H-pyran-3,4,5-triol (Figure 2). Such sodium-glucose co-transporters are responsible for reabsorbing glucose into the kidney [2-3].

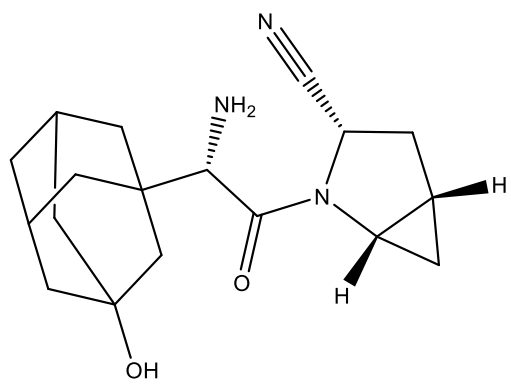

Figure 1. Structure of Saxagliptin.

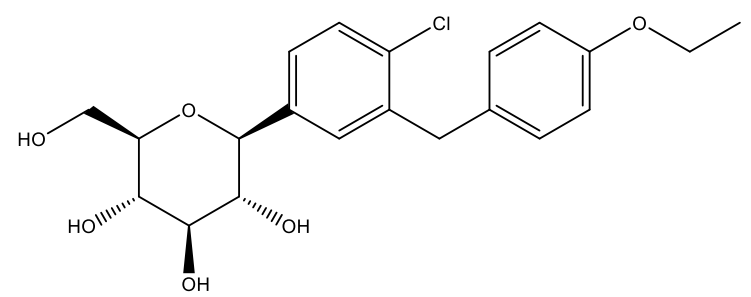

Figure 2. Structure of Dapagliflozin.

An extensive literature survey has revealed that there are few methods are reported for estimation of SAXA and DAPA individually or in combination with other drugs by UV Method [4-7], Reverse phase high performance liquid chromatographic (RP HPLC) method [8-16], tandem mass spectrometry method [17] or LC-MS [18-19]. So, we propose to develop methods that are more reliable, sensitive, and simple for simultaneous estimation of SAXA and DAPA in bulk as well as a pharmaceutical formulation. In the present work, we developed and validated the UV method and RP-HPLC method for the simultaneous estimation of saxagliptin hydrochloride and dapagliflozin in bulk drug and its formulation as per ICH guidelines Q2(R1) [20].

\section{Materials and Methods}

\subsection{Reagents and chemicals.}

CTX Lifesciences (Surat) and Zydus Healthcare (Ahmedabad) gifted the pure drug samples of Saxagliptin Hydrochloride and Dapagliflozin, respectively. HPLC grade Acetonitrile, HPLC grade methanol, and all other chemicals were obtained from LOBA. During the entire study, HPLC grade water was obtained from the Milli-Q.

\subsection{Instrumentation.}

Spectrophotometric experiments were run on Shimadzu UV-Visible Double Beam System UV-1800 Spectrophotometer, while Chromatography was performed with an HPLC Shimadzu LC-2010 device equipped with a quaternary pump, column oven, degasser, PDA detector, and LC solution program.

\subsection{UV Spectroscopic method (Method A).}

\subsubsection{Selection of solvent for SAXA and DAPA.}

Methanol was ideal for the spectrophotometric analysis of SAXA and DAPA, according to the solubility testing. SAXA solutions of 6-22 $\mu \mathrm{g} / \mathrm{mL}$ and DAPA solutions of $12-44 \mu \mathrm{g} / \mathrm{mL}$ were prepared in methanol, and the spectrum was recorded between 200-400 nm. 


\subsubsection{Preparation of internal standards.}

\subsubsection{SAXA standard stock solution $(500 \mu \mathrm{g} / \mathrm{mL})$.}

Weighed $5 \mathrm{mg}$ of SAXA to a volumetric flask of $10 \mathrm{~mL}$. The flask has been shaken and methanol is the amount to have a $500 \mu \mathrm{g} / \mathrm{mL}$ SAXA solution.

\subsubsection{DAPA standard stock solution $(1000 \mu \mathrm{g} / \mathrm{mL})$.}

Weighed and transferred $10 \mathrm{mg}$ of DAPA to a $10 \mathrm{ml}$ volumetric flask. The flask has been shaken up, and methanol was used to produce a $1000 \mu \mathrm{g} / \mathrm{mL}$ DAPA solution.

\subsubsection{SAXA standard working solution $(50 \mu \mathrm{g} / \mathrm{mL})$.}

A 10ml SAXA was taken and transferred from the above stock solution into a $100 \mathrm{ml}$ volumetric flask. The flask has been shaken, and methanol has been added to the mark for a solution containing SAXA $50 \mu \mathrm{g} / \mathrm{mL}$.

\subsubsection{DAPA standard working solution $(100 \mu \mathrm{g} / \mathrm{mL})$.}

$10 \mathrm{ml}$ of DAPA from the above stock solution was taken and transferred $100 \mathrm{~mL}$ volumetric flask. The flask was shaken, and volume was made up to the mark with methanol to give a solution containing $100 \mu \mathrm{g} / \mathrm{mL}$ of DAPA.

\subsubsection{Selection of analytical wavelength for SAXA and DAPA.}

6-22 $\mu \mathrm{g} / \mathrm{mL}$ solutions were prepared in diluents for SAXA, and between 200-400 nm of the spectrum was recorded. Similarly, DAPA solutions of 12-44 $\mu \mathrm{g} / \mathrm{mL}$ were prepared in diluents, and spectrums between 200-400 nm were recorded. The wavelength at which maximum absorbance was measured was called the drug's $\lambda$ max.

\subsubsection{Establishment of the calibration curve.}

Individually a calibration curve was plotted for SAXA over a concentration range of 6$22 \mu \mathrm{g} / \mathrm{mL}$ and for DAPA 12-44 $\mu \mathrm{g} / \mathrm{mL}$. Accurately calibrated SAXA and DAPA work-stock solution was transferred to volumetric flasks of $10 \mathrm{~mL}$ and diluted with methanol to the limit. The absorbance was measured at selected wavelengths 210 and $224 \mathrm{~nm}$ for each solution. For SAXA and DAPA, the calibration curves were constructed by plotting absorbance versus concentration, and the coefficient of regression was stated.

\subsubsection{Simultaneous equation method [21,22].}

A simultaneous equation approach was used for estimating SAXA and DAPA using spectrophotometry. This approach involves two wavelengths. Select one wavelength at which SAXA displays maximum absorbance, thus choosing the second wavelength at which DAPA displays maximum absorbance. At chosen wavelengths, i.e., $210 \mathrm{~nm}$ and $224 \mathrm{~nm}$, the absorptivity of both the drugs determined.

From the above data of absorptivity, the generated equation for both the drugs is as under simultaneous equation

$\mathrm{A} 1=\mathrm{ax} 1 \mathrm{cx}+\mathrm{ay} 1 \mathrm{cy}$

$\mathrm{A} 2=\mathrm{ax} 2 \mathrm{cx}+\mathrm{ay} 2 \mathrm{cy}$ 
where,

ax 1 and ax 2 are absorptivities of SAXA at 210 and $224 \mathrm{~nm}$, respectively ay 1 and ay 2 are absorptivities of DAPA at 210 and $224 \mathrm{~nm}$, respectively

A1 and A2 are absorbances of the diluted test sample at 210 and $224 \mathrm{~nm}$, respectively

Using Cramer's rule and matrices, the equation (1) and (2) can be written as,

$\mathrm{Cx}=(\mathrm{A} 2$ ay1 $-\mathrm{A} 1$ ay2 $) /($ ax2 ay1- ax1 ay2)

$\mathrm{Cy}=(\mathrm{A} 1$ ax2 $-\mathrm{A} 2 \mathrm{ax} 1) /(\mathrm{ax} 2$ ay1- ax1 ay2)

By putting the values of absorptivity

where 1) A1 and A2 are absorbances of the sample at 210nm and $224 \mathrm{~nm}$, respectively

2) $\mathrm{Cx}$ is the concentration of SAXA in $\mu \mathrm{g} / \mathrm{mL}$

3) $\mathrm{Cy}$ is the concentration of DAPA in $\mu \mathrm{g} / \mathrm{mL}$

\subsubsection{Method validation.}

A detailed and full validation of the system was carried out according to the Q2(R1) guidelines of the ICH. The approach has been checked for linearity, precision, and accuracy, analyte recovery, roughness, and reproducibility [23].

\subsubsection{Linearity.}

Appropriate aliquots from SAXA $(1.2-4.4 \mathrm{~mL})$ and DAPA $(1.2-4.4 \mathrm{~mL})$ standard working solution were transferred to different volumetric flasks of $10 \mathrm{ml}$ capacity separately. The volume was made up to the mark with methanol to obtain a concentration of $6-22 \mu \mathrm{g} / \mathrm{mL}$ of SAXA and 12-44 $\mu \mathrm{g} / \mathrm{mL}$ of DAPA. The solutions were analyzed at $210 \mathrm{~nm}$ and $224 \mathrm{~nm}$, and the calibration curve was constructed by plotting average Absorbance vs. Conc., and the regression equation was computed. The mean absorptivity values were also calculated for SAXA and DAPA.

\subsubsection{Precision.}

Intraday Precision. Lower, middle, and higher concentrations of the calibration curve were selected for intraday precision for SAXA and DAPA. Appropriate aliquots of SAXA (1.2, 2.8 , and $4.4 \mathrm{~mL})$ and DAPA $(1.2,2.8$, and $4.4 \mathrm{~mL})$ were transferred to different volumetric flasks of $10 \mathrm{ml}$ individually. The volume was made up to the mark with methanol to obtain concentrations of 6,14 , and $22 \mu \mathrm{g} / \mathrm{mL}$ of SAXA and 12,28 , and $44 \mu \mathrm{g} / \mathrm{mL}$ of DAPA, respectively. The solutions were analyzed at $210 \mathrm{~nm}$ and $224 \mathrm{~nm}$ three times on the same day, and absorbance was recorded.

Interday Precision. Lower, middle, and higher concentrations of the calibration curve were selected for intraday precision for SAXA and DAPA. Appropriate aliquots of SAXA (1.2, 2.8, and $4.4 \mathrm{~mL})$ and DAPA $(1.2,2.8$, and $4.4 \mathrm{~mL})$ were transferred to different volumetric flasks of $10 \mathrm{ml}$ individually. The volume was made up to the mark with methanol to obtain concentrations of 6,14 , and $22 \mu \mathrm{g} / \mathrm{mL}$ of SAXA and 12,28 , and $44 \mu \mathrm{g} / \mathrm{mL}$ of DAPA, respectively. The solutions were analyzed at $210 \mathrm{~nm}$ and $224 \mathrm{~nm}$ three times on three consecutive days, and absorbance was recorded.

\subsubsection{Repeatability.}

Aliquots of $2.8 \mathrm{~mL}$ of SAXA and $2.8 \mathrm{~mL}$ of DAPA were pipette out and transferred to volumetric flasks of $10 \mathrm{~mL}$ individually. The volume was made up to the mark with methanol 
to obtain concentrations of $14 \mu \mathrm{g} / \mathrm{mL}$ of SAXA and $28 \mu \mathrm{g} / \mathrm{mL}$ of DAPA, respectively. Repeatability was established by performing the experiment six times consecutively, and absorbances were recorded.

\subsubsection{Accuracy.}

The validity and reliability of the proposed method were evaluated using the standard method of addition via a recovery study. To check the accuracy of the proposed method recovery study, 3 different levels of standard addition (80 percent, 100 percent, and 120 percent) were performed from pre-analyzed samples.

\subsubsection{Limit of Detection (LOD).}

An individual analytical procedure's detection limit is the lowest quantity of the analyte in a sample that can be detected but not generally quantified as an exact value. The calibration curve was repeated six times, measuring the standard deviation of the intercepts and the mean of the slopes. Then, mathematical terms were used to calculate the LOD.

$\mathrm{LOD}=3.3 \sigma / \mathrm{S}$

where, $\sigma=$ the standard deviation of the response

$\mathrm{S}=$ the slope of the calibration curve

\subsubsection{Limit of Quantification (LOQ).}

The quantification limit of an analytical procedure is the lowest amount of analyte in a sample, which can be quantitatively determined with suitable precision and accuracy. The calibration curve was repeated six times, and the standard deviations of the intercepts and means of slopes were calculated. Then LOD was measured by using the mathematical expression.

$\mathrm{LOQ}=10 \sigma / \mathrm{S}$

where, $\sigma=$ the standard deviation of the response

$\mathrm{S}=$ the slope of the calibration curve

\subsubsection{Robustness.}

The robustness of an analytical procedure is a measurement of its capacity to remain unaffected by small, but deliberate variations in method parameters. The robustness of the developed method was tested by varying detection wavelength $( \pm 2 \mathrm{~nm})$ of optimized conditions.

\subsubsection{Assay of the developed formulation containing SAXA and DAPA.}

A quantity of equivalent to $5 \mathrm{mg}$ of SAXA and $10 \mathrm{mg}$ of DAPA was taken and dissolved in $10 \mathrm{~mL}$ of methanol. The solution was filtered through Whatman filter paper no. 41. From this $1 \mathrm{~mL}$ was pipette out in a $100 \mathrm{~mL}$ volumetric flask, and volume was made up to mark to obtain $50 \mu \mathrm{g} / \mathrm{mL}$ of SAXA and $100 \mu \mathrm{g} / \mathrm{mL}$ of DAPA. The final solution having a concentration of $14 \mu \mathrm{g} / \mathrm{mL}$ of SAXA and $28 \mu \mathrm{g} / \mathrm{mL}$ of DAPA was prepared and analyzed. 


\subsection{RP-HPLC Method.}

\subsubsection{Preparation of standard stock solution.}

5mg of SAXA and $10 \mathrm{mg}$ DAPA were weighed separately and transferred to $10 \mathrm{~mL}$ volumetric flasks. Both of them were dissolved in methanol, and volume was made up to mark with methanol giving final solution containing $500 \mu \mathrm{g} / \mathrm{mL}$ and $1000 \mu \mathrm{g} / \mathrm{mL}$, respectively.

\subsubsection{Preparation of binary mixture.}

$10 \mathrm{ml}$ of SAXA and DAPA standard stock solution was added to $100 \mathrm{~mL}$ volumetric flask, and volume was made up to mark with methanol to obtain a mixture containing $50 \mu \mathrm{g} / \mathrm{mL}$ and $100 \mu \mathrm{g} / \mathrm{mL}$, respectively.

\subsubsection{Preparation of mobile phase.}

The mobile phase acetonitrile was filtered through a 0.45 micron pore size membrane filter using vacuum filtration assembly. Phosphate buffer was prepared, and $\mathrm{pH}$ was adjusted with glacial acetic acid ( $\mathrm{pH} 4)$.

\subsubsection{Validation of developed RP-HPLC method.}

Validation was done as per ICH guideline Q2 (R1). The developed RP-HPLC methods were validated concerning parameters such as linearity, precision, accuracy, specificity, robustness.

\subsubsection{Linearity.}

Linearity was studied by preparing a standard solution at 6 different concentrations. Each concentration was repeated 6 times. The preparation of solutions for the calibration curve for the linearity study was done by the following procedure. Aliquot equivalent to 1.6, 2.0, 2.4, 2.8, 3.2, 3.6, 4.0, $4.4 \mathrm{~mL}$ of solution was transferred into $10 \mathrm{ml}$ volumetric flasks and diluted up to the mark by using methanol. From each solution, $20 \mu \mathrm{L}$ volume was injected into the HPLC system and analyzed. The calibration curve was obtained by plotting the respective peak area against concentration in $\mu \mathrm{g} / \mathrm{mL}$, and the regression equation was computed.

The linearity of SAXA and DAPA was found $8-22 \mu \mathrm{g} / \mathrm{mL}$ and $16-44 \mu \mathrm{g} / \mathrm{mL}$, respectively. Linearity was assessed in terms of slope, intercept, and correlation coefficient.

\subsubsection{Precision.}

Intraday Precision. Intraday precision was determined by analyzing the sample solution three times in one day for three different concentrations. (Combined standard samples of concentrations 10, 16, $22 \mu \mathrm{g} / \mathrm{mL}$ for SAXA and 20,32, $44 \mu \mathrm{g} / \mathrm{mL}$ for DAPA).

Interday Precision. Interday precision was determined by analyzing the sample solution on three different days for three different concentrations. (Combined standard samples of concentrations 10, 16, $22 \mu \mathrm{g} / \mathrm{mL}$ for SAXA and 20,32, $44 \mu \mathrm{g} / \mathrm{mL}$ for DAPA).

\subsubsection{Repeatability.}

To demonstrate precision, repeated measurement of the developed method was checked. Six sets of both $(16 \mu \mathrm{g} / \mathrm{mL}$ of SAXA and $32 \mu \mathrm{g} / \mathrm{mL}$ of DAPA) were prepared. 
Duplicate injections of each set of assay preparation into liquid chromatography were injected and chromatograms were recorded. The repeatability was expressed in terms of relative standard deviation (RSD).

\subsubsection{Accuracy.}

The accuracy of the method was carried out at three levels in the range of 80, 100, and $120 \%$ of the working concentration of the sample. The calculated amount of SAXA and DAPA working standard solutions were added in the sample solution-containing volumetric flask to prepare $80 \%, 100 \%$, and $120 \%$ level of the working concentration.

For $80 \%$ level of recovery, $2 \mathrm{~mL}$ of the sample solution and $1.6 \mathrm{~mL}$ of standard solution was pipette out in a $10 \mathrm{ml}$ volumetric flask. The volume was made up to the mark with methanol to obtain a final concentration of $18 \mu \mathrm{g} / \mathrm{mL}$ of SAXA and $36 \mu \mathrm{g} / \mathrm{ml}$ of DAPA. The solution was analyzed three times, and areas were recorded.

For a $100 \%$ level of recovery, $2 \mathrm{~mL}$ of the sample solution and $2 \mathrm{~mL}$ of standard solution was pipette out in a $10 \mathrm{ml}$ volumetric flask. The volume was made up to the mark with methanol to obtain a final concentration of $20 \mu \mathrm{g} / \mathrm{mL}$ of SAXA and $40 \mu \mathrm{g} / \mathrm{mL}$ of DAPA. The solution was analyzed three times, and areas were recorded.

For a $120 \%$ level of recovery, $2 \mathrm{~mL}$ of the sample solution and $2.4 \mathrm{~mL}$ of standard solution was pipette out in a $10 \mathrm{ml}$ volumetric flask. The volume was made up to the mark with methanol to obtain a final concentration of $22 \mu \mathrm{g} / \mathrm{mL}$ of SAXA and $44 \mu \mathrm{g} / \mathrm{mL}$ of DAPA. The solution was analyzed three times, and areas were recorded.

\subsubsection{5. $L O D$ and $L O Q$.}

The calibration curve was repeated three times, and the standard deviation (SD) of the intercepts was calculated. The limit of detection (LOD) and limit of quantification (LOQ) of the drug were derived by calculating the signal-to-noise (i.e., 3.3 for LOD and 10 for LOQ) ratio using the following equations

$\mathrm{LOD}=3.3 \mathrm{\sigma} / \mathrm{S}$ and $\mathrm{LOQ}=10 \mathrm{\sigma} / \mathrm{S}$

where, $\sigma=$ Standard deviation of the response

$\mathrm{S}=$ Slope of the calibration curve

\subsubsection{Robustness.}

The robustness of the developed method was tested by varying detection wavelength $( \pm 2 \mathrm{~nm})$, flow rate $( \pm 1 \mathrm{~mL} / \mathrm{min})$ of optimized conditions. There were changed the following parameters, one by one, and observed their effect on system suitability test and assay.

Changed wavelength by $\pm 2 \mathrm{~nm}$. Appropriate aliquot, $2.8 \mathrm{~mL}$ was taken from a working standard solution into a $10 \mathrm{~mL}$ volumetric flask. The volume was made up to the mark with methanol to obtain a concentration of $14 \mu \mathrm{g} / \mathrm{mL}$ of SAXA and $28 \mu \mathrm{g} / \mathrm{mL}$ of DAPA. This solution was analyzed at an optimized HPLC condition changed flow rate $( \pm 2 \mathrm{~nm})$ to check robustness.

Changed flow rate by $+2 \mathrm{~mL} / \mathrm{min}$. Appropriate aliquot, $2.8 \mathrm{~mL}$ was taken from a working standard solution into a $10 \mathrm{~mL}$ volumetric flask. The volume was made up to the mark with methanol to obtain a concentration of $14 \mu \mathrm{g} / \mathrm{mL}$ of SAXA and $28 \mu \mathrm{g} / \mathrm{mL}$ of DAPA. This solution was analyzed at an optimized HPLC condition changed flow rate $( \pm 1 \mathrm{~mL} / \mathrm{min})$ to check robustness. 


\subsubsection{Assay of the marketed formulation by RP-HPLC method.}

Weigh 20 tablets and determine average weight. Accurately weigh and transfer the quantity of tablet contents equivalent to about $5 \mathrm{mg}$ of SAXA and $10 \mathrm{mg}$ of DAPA transfer into a $10 \mathrm{~mL}$ amber-colored volumetric flask and add methanol and sonicated for about $20 \mathrm{~min}$. Dilute it up to mark with methanol and mix to get a solution containing $500 \mu \mathrm{g} / \mathrm{mL}$ of SAXA and $1000 \mu \mathrm{g} / \mathrm{mL}$ of DAPA. Take $10 \mathrm{~mL}$ aliquot in a separate $100 \mathrm{~mL}$ amber-colored volumetric flask. Dilute it up to mark with methanol to get a solution containing $50 \mu \mathrm{g} / \mathrm{mL}$ of SAXA and $100 \mu \mathrm{g} / \mathrm{mL}$ of DAPA. Take $3.2 \mathrm{~mL}$ of an aliquot in a separate $10 \mathrm{ml}$ amber colored volumetric flask. Dilute it up to mark with methanol to get a solution containing $16 \mu \mathrm{g} / \mathrm{mL}$ of SAXA and $32 \mu \mathrm{g} / \mathrm{mL}$ of DAPA. The analysis procedure was repeated 5 times.

\section{Results and Discussion}

\subsection{Method Validation (UV Method).}

\subsubsection{Linearity.}

Linearity was found between 6 to $22 \mu \mathrm{g} / \mathrm{mL}$ for SAXA (Figure 3) and 12 to $44 \mu \mathrm{g} / \mathrm{mL}$ DAPA (Figure 4), respectively. Linear regression data for the calibration curves $(n=6)$ shows a good linear relationship over the concentration range of 6 to $22 \mu \mathrm{g} / \mathrm{mL}$ for SAXA (Figure 5,6 ) and 12 to $44 \mu \mathrm{g} / \mathrm{mL}$ DAPA (Figure 7,8) respectively. The solutions were analyzed at $210 \mathrm{~nm}$ and $224 \mathrm{~nm}$, and the calibration curve was constructed by plotting average Absorbance vs. Conc., and the regression equation was computed.

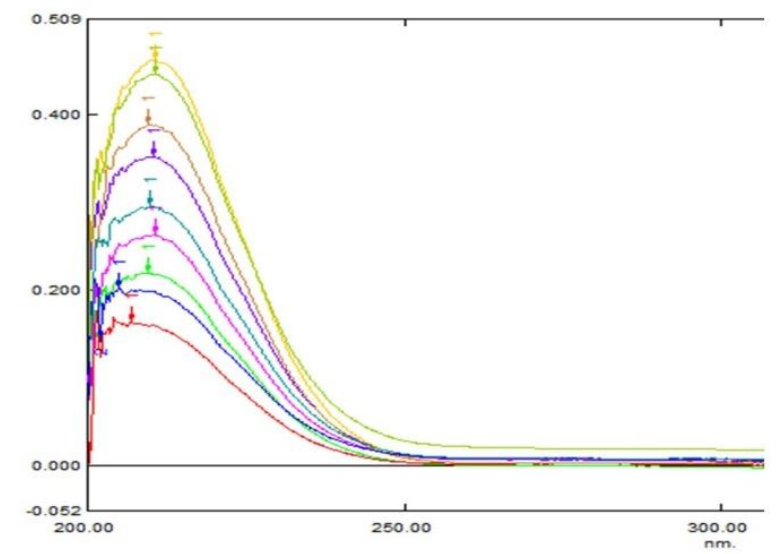

Figure 3. Overlay spectra of SAXA (6 to $22 \mu \mathrm{g} / \mathrm{mL}$ ) in methanol at $210 \mathrm{~nm}$.

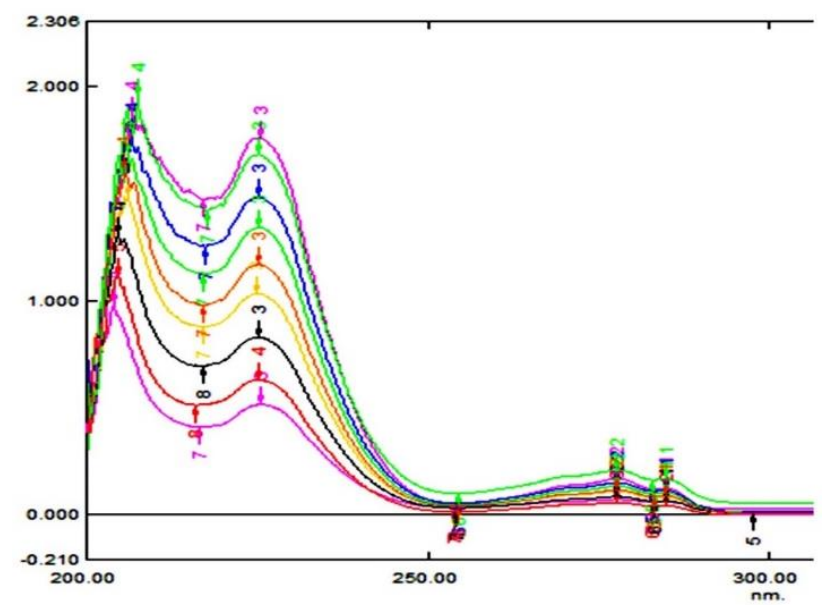

Figure 4. Overlay spectra of DAPA (12 to $44 \mu \mathrm{g} / \mathrm{mL})$ in methanol at $224 \mathrm{~nm}$. 


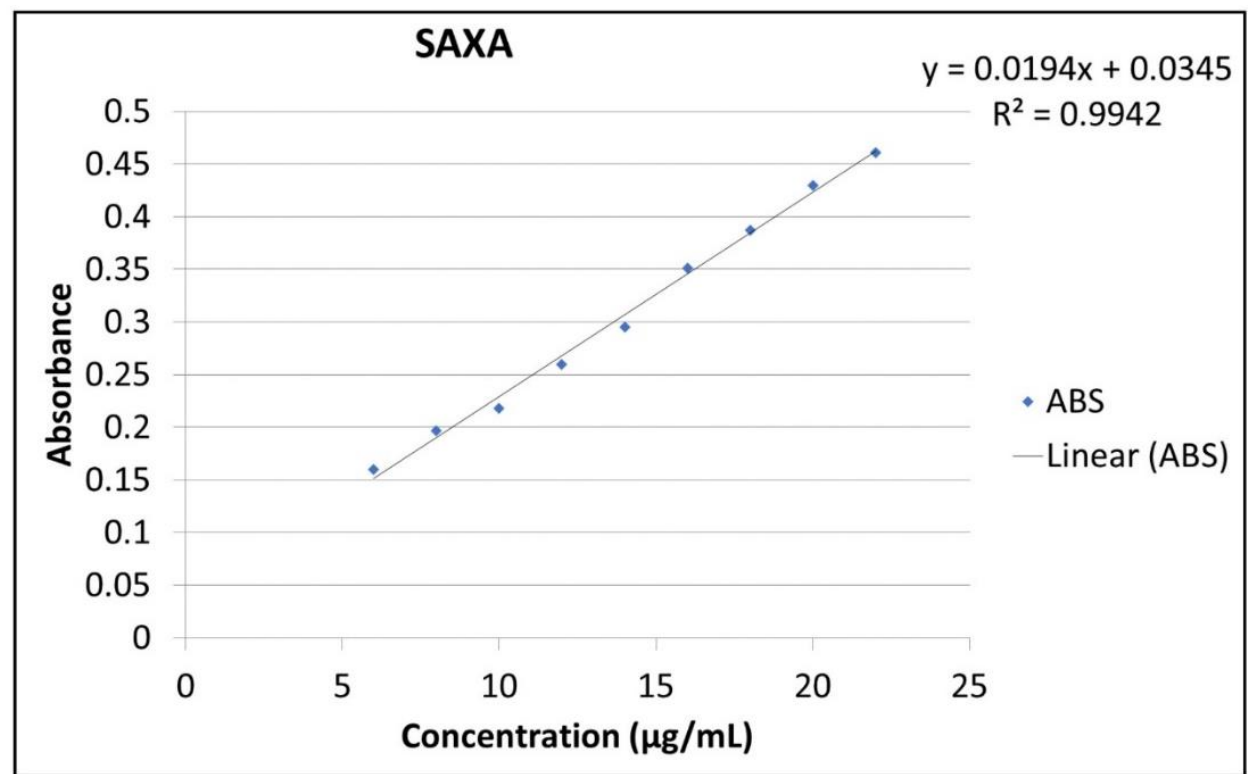

Figure 5. Calibration curve for SAXA at $210 \mathrm{~nm}$.

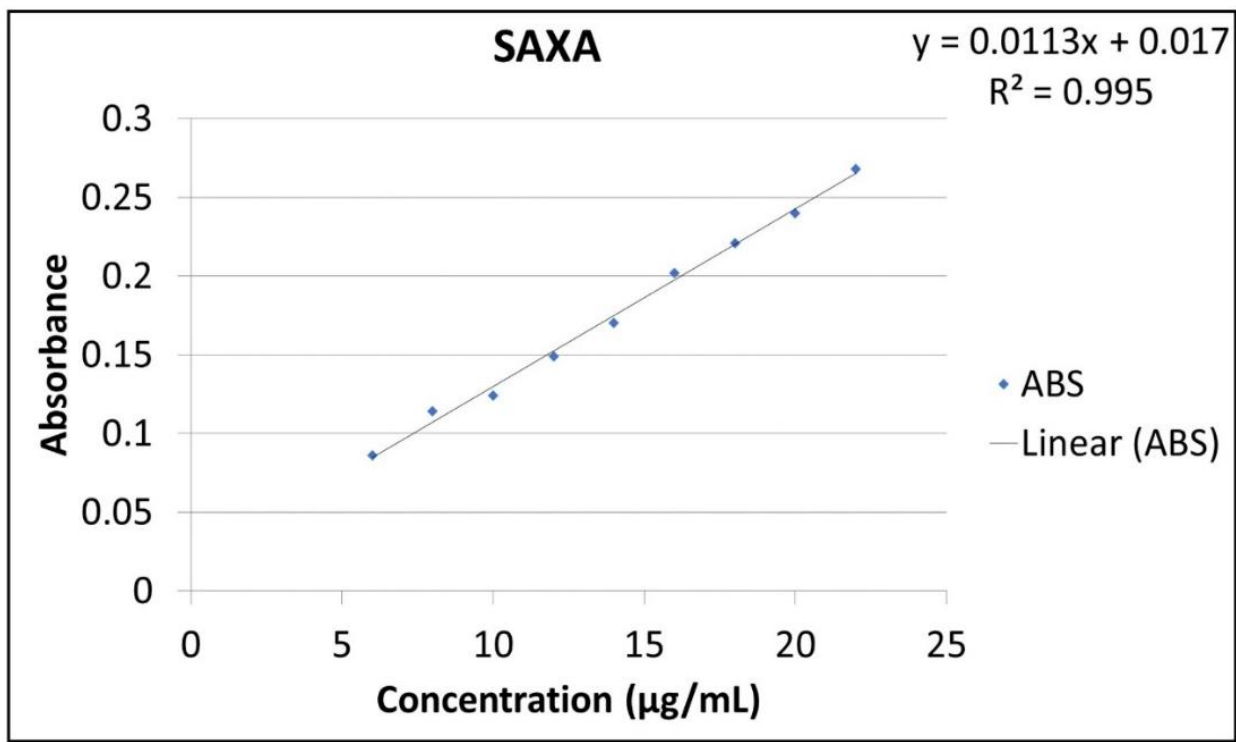

Figure 6. Calibration curve for SAXA at $224 \mathrm{~nm}$.

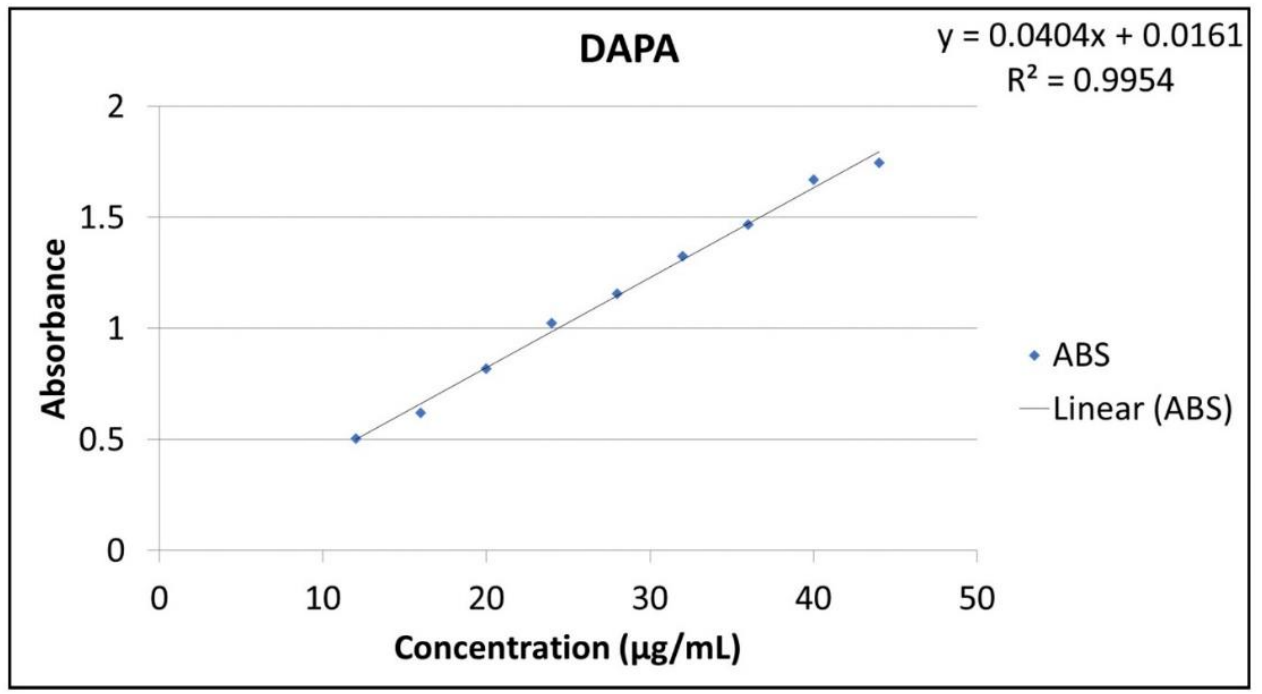

Figure 7. Calibration curve for DAPA at $224 \mathrm{~nm}$. 


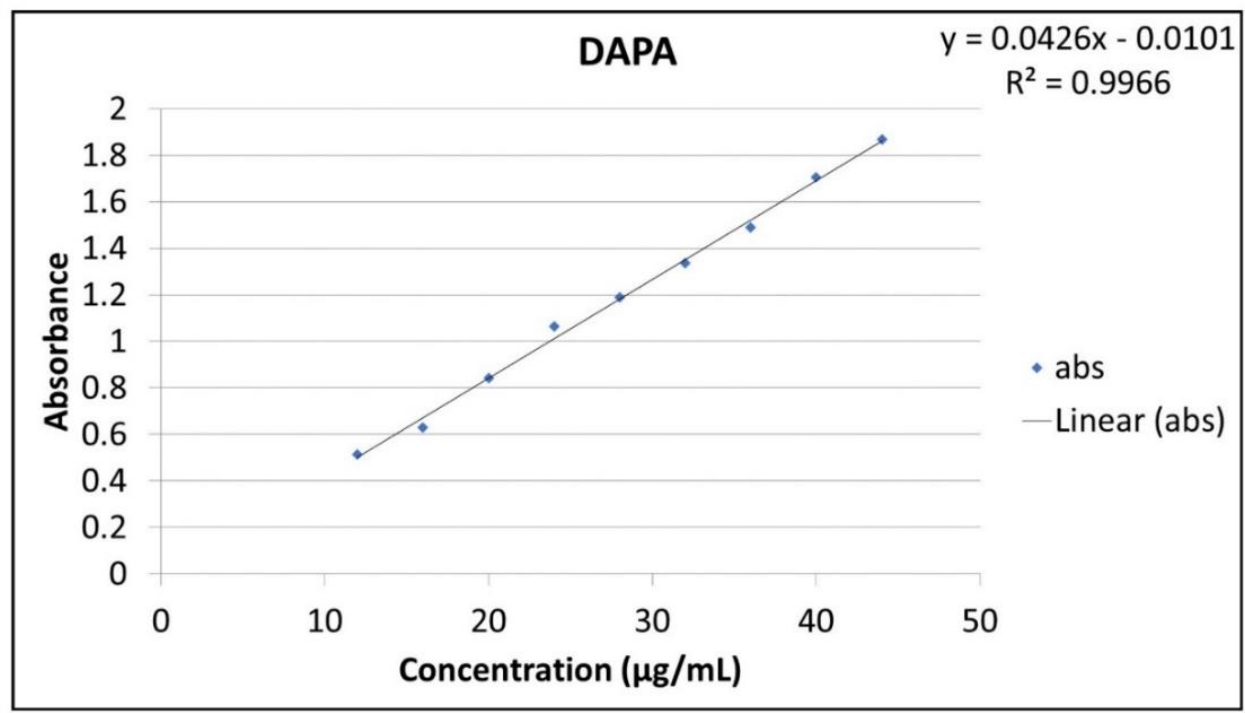

Figure 8. Calibration curve for DAPA at $210 \mathrm{~nm}$.

\subsubsection{Precision.}

\subsubsection{Intraday precision.}

Intraday precision was performed, and \%RSD values were within the acceptance criteria.

\subsubsection{Interday precision.}

Interday precision was performed and \% RSD values were well within the acceptance criteria.

\subsubsection{Repeatability.}

It was performed, and \%RSD values were found to be less than $2 \%$.

\subsubsection{Accuracy.}

Accuracy was performed, and \% Recovery was found to be within 98-102\% at all three levels. This indicates that SAXA and DAPA can be recovered successfully in the presence of excipients. (As shown in Table 1 and 2).

Table 1. Accuracy (\% Recovery) data for SAXA at $210 \mathrm{~nm}(\mathrm{n}=3)$.

\begin{tabular}{|c|c|c|c|c|c|c|c|c|}
\hline $\begin{array}{l}\text { Level of } \\
\text { recovery }\end{array}$ & $\begin{array}{c}\text { Sample } \\
\text { Conc. } \\
(\mu \mathrm{g} / \mathrm{mL})\end{array}$ & $\begin{array}{c}\text { Conc. of Std } \\
\text { added }(\mu \mathrm{g} / \mathrm{mL})\end{array}$ & $\begin{array}{c}\text { Total } \\
\text { Conc. } \\
(\mu \mathrm{g} / \mathrm{mL})\end{array}$ & Abs & $\begin{array}{c}\text { Mean } \\
\text { Abs }^{1}\end{array}$ & $\begin{array}{c}\text { Amt } \\
\text { Recovered } \\
(\mu \mathrm{g} / \mathrm{mL})\end{array}$ & $\begin{array}{c}\% \\
\text { Recovery }\end{array}$ & $\%$ RSD \\
\hline \multirow[t]{3}{*}{$80 \%$} & \multirow[t]{3}{*}{10} & \multirow[t]{3}{*}{8} & \multirow[t]{3}{*}{18} & 0.387 & \multirow[t]{3}{*}{0.384} & \multirow[t]{3}{*}{18.01} & \multirow[t]{3}{*}{100.08} & \multirow[t]{3}{*}{0.09} \\
\hline & & & & 0.385 & & & & \\
\hline & & & & 0.380 & & & & \\
\hline \multirow[t]{3}{*}{$100 \%$} & \multirow[t]{3}{*}{10} & \multirow[t]{3}{*}{10} & \multirow[t]{3}{*}{20} & 0.430 & \multirow[t]{3}{*}{0.429} & \multirow[t]{3}{*}{20.33} & \multirow[t]{3}{*}{101.67} & \multirow[t]{3}{*}{0.07} \\
\hline & & & & 0.433 & & & & \\
\hline & & & & 0.425 & & & & \\
\hline \multirow[t]{3}{*}{$120 \%$} & \multirow[t]{3}{*}{10} & \multirow[t]{3}{*}{12} & \multirow[t]{3}{*}{22} & 0.461 & \multirow[t]{3}{*}{0.460} & \multirow[t]{3}{*}{21.93} & \multirow[t]{3}{*}{99.69} & \multirow[t]{3}{*}{0.05} \\
\hline & & & & 0.465 & & & & \\
\hline & & & & 0.455 & & & & \\
\hline
\end{tabular}

${ }^{1}$ Mean absorbance of $n=3$ 
Table 2. Accuracy (\% Recovery) data for DAPA at $224 \mathrm{~nm}(\mathrm{n}=3)$.

\begin{tabular}{|c|c|c|c|c|c|c|c|c|}
\hline $\begin{array}{l}\text { Level of } \\
\text { recovery }\end{array}$ & $\begin{array}{c}\text { Sample } \\
\text { Conc. } \\
(\mu \mathrm{g} / \mathrm{mL})\end{array}$ & $\begin{array}{c}\text { Conc. Of } \\
\text { Std added } \\
(\mu \mathrm{g} / \mathrm{mL})\end{array}$ & $\begin{array}{c}\text { Total } \\
\text { Conc. } \\
(\mu \mathrm{g} / \mathrm{mL})\end{array}$ & Abs & $\begin{array}{c}\text { Mean } \\
\text { Abs }^{1}\end{array}$ & $\begin{array}{c}\text { Amt } \\
\text { Recovered } \\
(\mu \mathrm{g} / \mathrm{mL})\end{array}$ & $\begin{array}{c}\% \\
\text { Recovery }\end{array}$ & $\%$ RSD \\
\hline \multirow{3}{*}{$80 \%$} & \multirow{3}{*}{20} & \multirow{3}{*}{16} & \multirow{3}{*}{36} & 1.469 & \multirow{3}{*}{1.483} & \multirow{3}{*}{36.3} & \multirow{3}{*}{100.83} & \multirow{3}{*}{0.22} \\
\hline & & & & 1.478 & & & & \\
\hline & & & & 1.502 & & & & \\
\hline \multirow{3}{*}{$100 \%$} & \multirow{3}{*}{20} & \multirow{3}{*}{20} & \multirow{3}{*}{40} & 1.651 & \multirow{3}{*}{1.662} & \multirow{3}{*}{40.74} & \multirow[t]{3}{*}{101.85} & \multirow{3}{*}{0.87} \\
\hline & & & & 1.682 & & & & \\
\hline & & & & 1.655 & & & & \\
\hline \multirow{3}{*}{$120 \%$} & \multirow{3}{*}{20} & \multirow{3}{*}{24} & \multirow{3}{*}{44} & 1.745 & \multirow{3}{*}{1.761} & \multirow{3}{*}{43.19} & \multirow{3}{*}{98.15} & \multirow{3}{*}{0.30} \\
\hline & & & & 1.752 & & & & \\
\hline & & & & 1.786 & & & & \\
\hline
\end{tabular}

${ }^{1}$ Mean absorbance of $n=3$

3.1.5. LOD and LOQ.

LOD and LOQ values were calculated using the mathematical equation.

\subsubsection{Robustness.}

The robustness of the developed method was checked by varying the $\lambda$ max. The results show that $\%$ RSD values are less than $2 \%$ at varied maxima indicating that the developed method is robust in terms of change in $\lambda \max$ by $\pm 2 \mathrm{~nm}$.

\subsubsection{Analysis of the developed formulation.}

The results of the assay were found to be within of label claim for formulations containing SAXA and DAPA as shown in Table 3.

Table 3. Assay data for SAXA and DAPA $(n=3)$

\begin{tabular}{|c|c|c|c|c|}
\hline Drug & Label Claim (mg) & $\begin{array}{c}\text { Sample conc. } \\
(\mu \mathrm{g} / \mathbf{m L})\end{array}$ & Abs at $210 \mathrm{~nm}$ & Abs at $224 \mathrm{~nm}$ \\
\hline \multirow{3}{*}{ SAXA } & \multirow{3}{*}{5} & \multirow{3}{*}{14} & 0.305 & 0.175 \\
\hline & & & 0.310 & 0.178 \\
\hline & & & 0.308 & 0.174 \\
\hline \multicolumn{3}{|c|}{$\%$ Assay \pm SD } & $100.33 \pm 0.002$ & $99.87 \pm 0.002$ \\
\hline \multicolumn{3}{|c|}{ \%RSD } & 0.81 & 1.18 \\
\hline \multirow{3}{*}{ DAPA } & \multirow{3}{*}{10} & \multirow{3}{*}{28} & 1.195 & 1.165 \\
\hline & & & 1.180 & 1.149 \\
\hline & & & 1.182 & 1.142 \\
\hline \multicolumn{3}{|c|}{$\%$ Assay \pm SD } & $100.19 \pm 0.008$ & $100.41 \pm 0.011$ \\
\hline \multicolumn{3}{|c|}{ \% RSD } & 0.68 & 1.02 \\
\hline
\end{tabular}

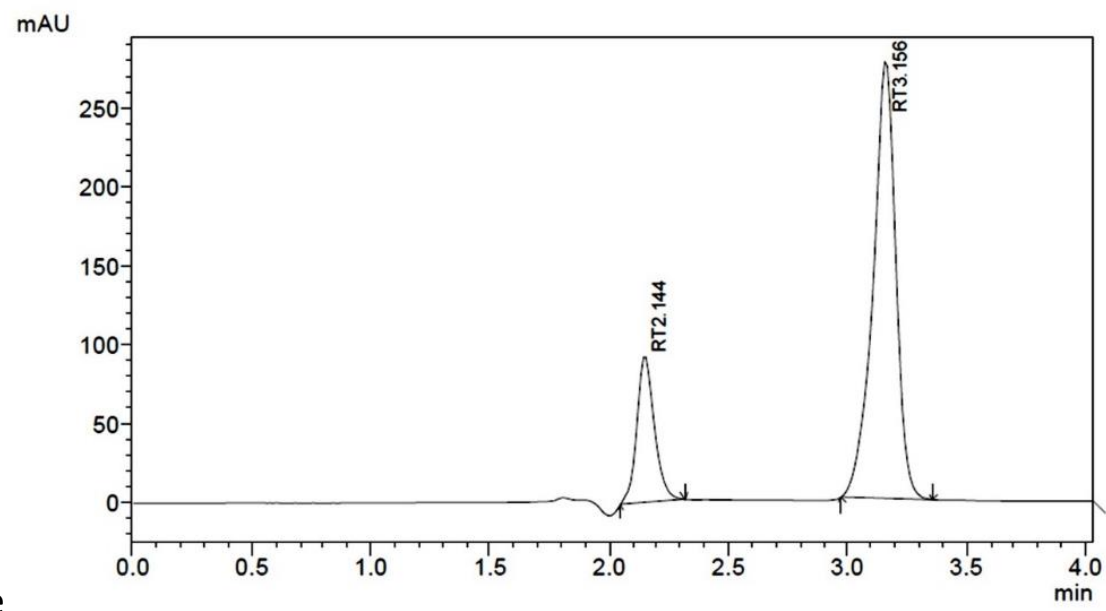

Figure 9. Developed chromatogram of SAXA $(16 \mu \mathrm{g} / \mathrm{mL})$ and DAPA $(32 \mu \mathrm{g} / \mathrm{mL})$ by HPLC. 


\subsection{HPLC method.}

Various trials for varying ratios of the mobile phase, gradient system, diluents, wavelength, flow, column, and column temperature were performed. The final chromatographic conditions are mentioned below based on trials, as mentioned in Table 4, while the optimized chromatography is shown in Figure 9.

Table 4. Optimized chromatographic condition.

\begin{tabular}{l|l} 
Parameter & Condition \\
\hline HPLC & Shimadzu HPLC system equipped quaternary pump and PDA detector \\
\hline Column & C18 Inertsil ODS $(150 \times 4.6) \mathrm{mm}, 5 \mu$ \\
\hline Mobile phase & Phosphate buffer: Acetonitrile $(55: 45), \mathrm{pH} 4.0$ adjusted by glacial acetic acid \\
\hline Flow rate & $0.8 \mathrm{~mL} / \mathrm{min}$ \\
\hline Injection volume & $20 \mu \mathrm{L} / \mathrm{min}$ \\
\hline Detection Wavelength & $220 \mathrm{~nm}$ \\
\hline Run time & $5 \mathrm{~min}$ \\
\hline Diluent & Methanol \\
\hline Oven Temperature & $25^{\circ} \mathrm{C}$
\end{tabular}

\subsubsection{RP-HPLC method validation.}

The developed HPLC method was validated as per ICH Q2 (R1) guidelines.

\subsubsection{System suitability.}

System suitability was assessed using a sample as six homogenous injections. (Table $5)$.

Table 5. Data of developed method by HPLC of SAXA and DAPA.

\begin{tabular}{c|c|c|c|c|c} 
Drug Name & Retention Time & Area & Tailing Factor & Theoretical Plate & Resolution \\
\hline SAXA & 2.144 & 406272 & 1.272 & 3188.124 & -- \\
\hline DAPA & 3.156 & 1656776 & 0.925 & 3702.009 & 4.865
\end{tabular}

\subsubsection{Linearity.}

Overlay chromatogram of mixture showing linearity of SAXA $(8-22 \mu \mathrm{g} / \mathrm{mL})$ and DAPA $(22-44 \mu \mathrm{g} / \mathrm{mL})$ at $220 \mathrm{~nm}$ (Figure 10). The regression data for the calibration curves $(\mathrm{n}=6)$ shows a good linearity relationship over the concentration range of $8-22 \mu \mathrm{g} / \mathrm{mL}$ for SAXA (Figure 11) and 16-44 $\mu \mathrm{g} / \mathrm{mL}$ for DAPA (Figure 12) in mixture with respect to the peak area. Linearity data of SAXA and DAPA shows \%RSD less than 2. (Table 6).

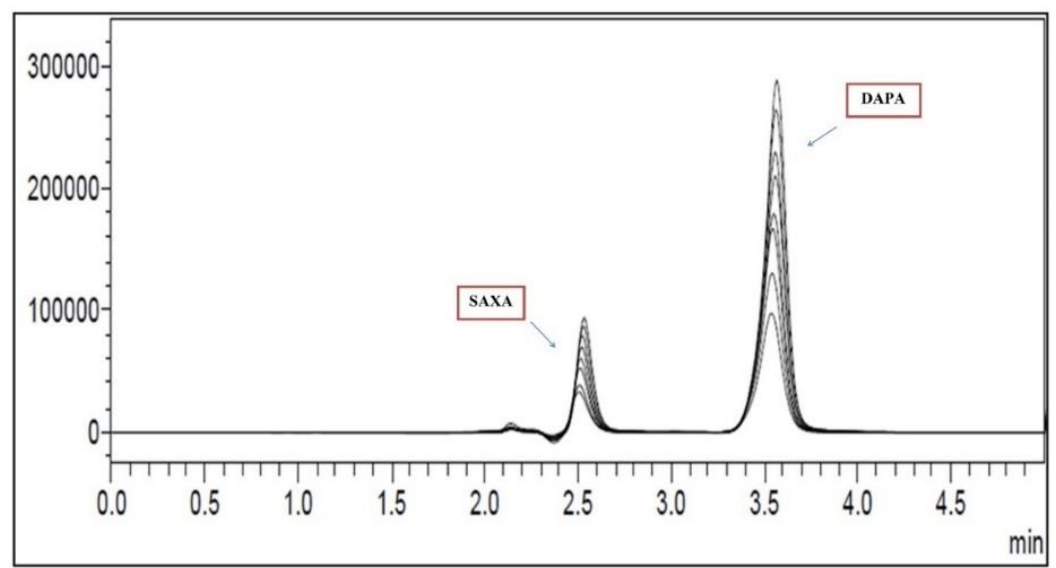

Figure 10. Overlay chromatogram of mixture showing linearity of SAXA $(8-22 \mu \mathrm{g} / \mathrm{mL})$ and DAPA $(22-44$ $\mu \mathrm{g} / \mathrm{mL})$ at $220 \mathrm{~nm}$. 


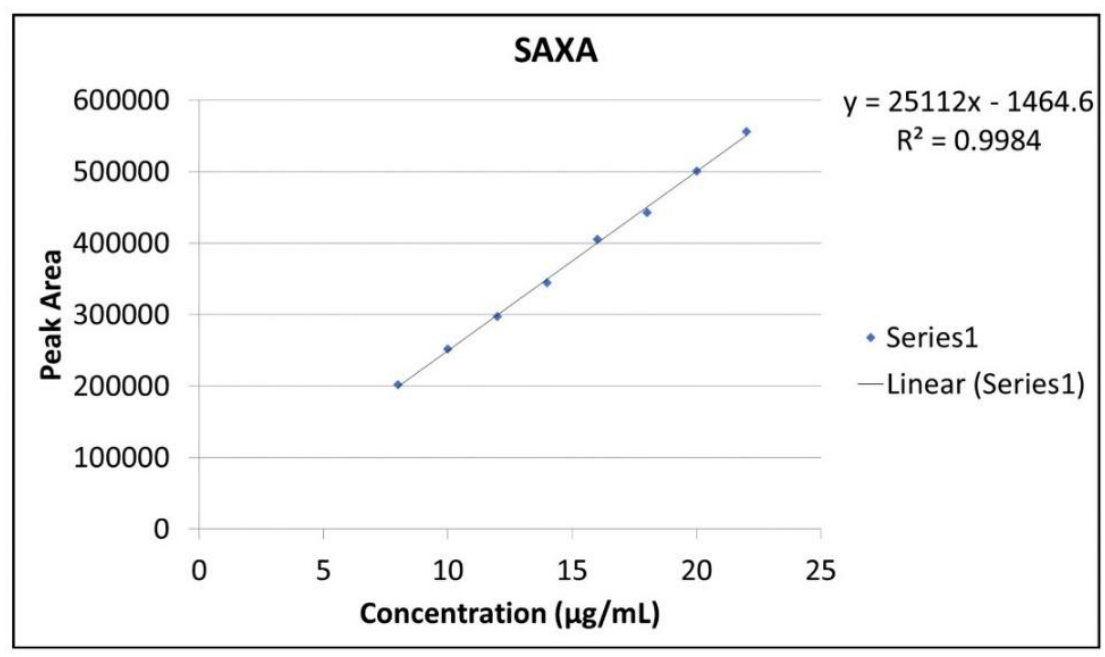

Figure 11. Calibration Curve for SAXA.

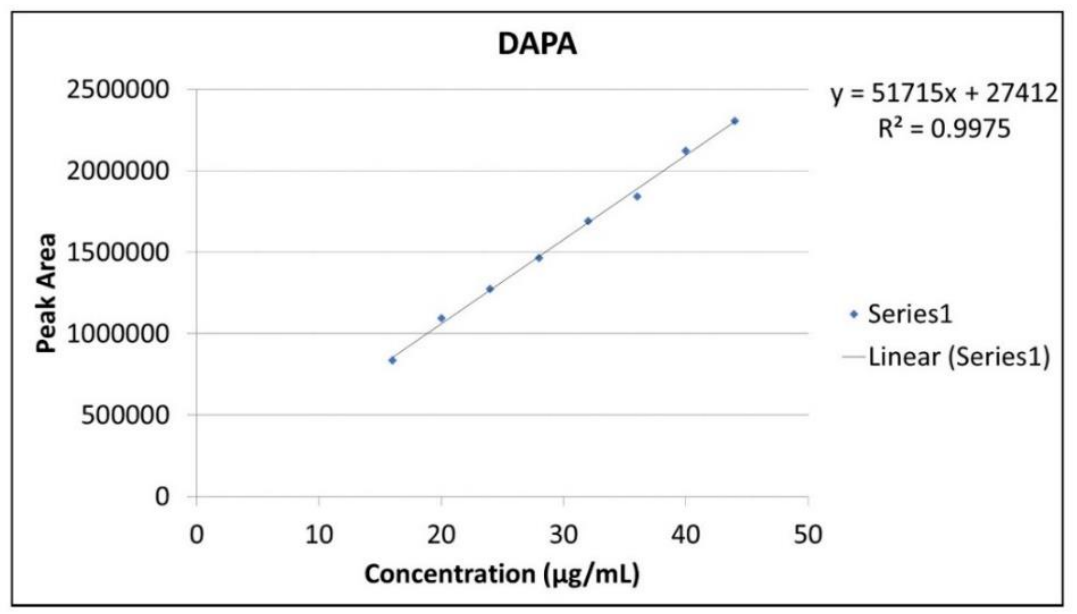

Figure 12. Calibration Curve for DAPA.

Table 6. Linearity data of SAXA and DAPA $(n=6)$.

\begin{tabular}{|c|c|c|c|c|c|c|}
\hline \multirow[t]{2}{*}{ Sr. No. } & \multicolumn{3}{|c|}{ SAXA } & \multicolumn{3}{|c|}{ DAPA } \\
\hline & Conc. $(\mu \mathrm{g} / \mathrm{mL})$ & Peak area ${ }^{1}$ Mean \pm SD & $\%$ RSD & Conc. $(\mu \mathrm{g} / \mathrm{mL})$ & Peak area ${ }^{1}$ Mean \pm SD & \%RSD \\
\hline 1. & 8 & $202156 \pm 4410$ & 1.18 & 16 & $834613 \pm 3958$ & 0.47 \\
\hline 2. & 10 & $252329 \pm 1830$ & 0.72 & 20 & $1095381 \pm 638$ & 0.05 \\
\hline 3. & 12 & $297284 \pm 5386$ & 1.81 & 24 & $1273055 \pm 9887$ & 0.77 \\
\hline 4. & 14 & $344760 \pm 1398$ & 0.40 & 28 & $1463528 \pm 2191$ & 0.14 \\
\hline 5. & 16 & $405429 \pm 2821$ & 0.69 & 32 & $1691868 \pm 30634$ & 1.81 \\
\hline 6. & 18 & $442463 \pm 1163$ & 1.62 & 36 & $1843934 \pm 3596$ & 0.19 \\
\hline 7. & 20 & $500817 \pm 1233$ & 0.24 & 40 & $2122818 \pm 7747$ & 0.36 \\
\hline \multirow[t]{3}{*}{8.} & 22 & $556461 \pm 4073$ & 0.73 & 44 & $2305784 \pm 8416$ & 0.36 \\
\hline & \multicolumn{3}{|c|}{$\begin{array}{l}\text { Linearity Equation } \\
\mathrm{y}=25112 \mathrm{x}-1464.6\end{array}$} & \multicolumn{3}{|c|}{$\begin{array}{l}\text { Linearity Equation } \\
\mathrm{y}=51715 \mathrm{x}+27412\end{array}$} \\
\hline & \multicolumn{3}{|c|}{$\mathbf{R}^{2}=0.9984$} & \multicolumn{3}{|c|}{$\mathbf{R}^{2}=0.9975$} \\
\hline
\end{tabular}

${ }^{1}$ Mean area of $\mathrm{n}=6$.

\subsubsection{Precision.}

The \%RSD value of each concentration for intraday and interday precision for SAXA and DAPA was found NMT 2\%. This value shows that the developed method was precise. 


\subsubsection{Repeatability.}

The six-replicate injection for both the drugs was injected, and the chromatogram is recorded for the same concentration. The relative standard deviation was found to be NMT $2 \%$, indicating that the method is repeatable.

\subsubsection{Accuracy.}

Accuracy was performed, and \% Recovery was found to be within 98-102\% at all three levels. This indicates that the SAXA (Table 7) and DAPA (Table 8) can be recovered successfully in presence of excipients.

Table 7. Accuracy data of SAXA ( $n=3)$.

\begin{tabular}{|c|c|c|c|c|c|c|c|}
\hline $\begin{array}{l}\text { Level of } \\
\text { recovery }\end{array}$ & $\begin{array}{l}\text { Sample Conc. } \\
(\mu \mathrm{g} / \mathrm{mL})\end{array}$ & $\begin{array}{c}\text { Conc. of Std } \\
\text { added }(\mu \mathrm{g} / \mathrm{mL})\end{array}$ & $\begin{array}{c}\text { Total } \\
\text { Conc. } \\
(\mu \mathrm{g} / \mathrm{mL}) \\
\end{array}$ & $\begin{array}{l}\text { Peak } \\
\text { Area }\end{array}$ & $\begin{array}{c}\text { Mean Peak } \\
\text { Area }^{1}\end{array}$ & $\begin{array}{c}\text { Amt. } \\
\text { Recovered } \\
(\mu \mathrm{g} / \mathrm{mL})\end{array}$ & $\begin{array}{c}\% \\
\text { Recovery }\end{array}$ \\
\hline \multirow{3}{*}{$80 \%$} & \multirow{3}{*}{10} & \multirow{3}{*}{8} & \multirow{3}{*}{18} & 443546 & \multirow{3}{*}{445178} & \multirow{3}{*}{17.78} & \multirow{3}{*}{98.81} \\
\hline & & & & 445864 & & & \\
\hline & & & & 446126 & & & \\
\hline \multirow{3}{*}{$100 \%$} & \multirow{3}{*}{10} & \multirow{3}{*}{10} & \multirow{3}{*}{20} & 484208 & \multirow{3}{*}{491868} & \multirow{3}{*}{19.64} & \multirow{3}{*}{98.22} \\
\hline & & & & 499315 & & & \\
\hline & & & & 492083 & & & \\
\hline \multirow{3}{*}{$120 \%$} & \multirow{3}{*}{10} & \multirow{3}{*}{12} & \multirow{3}{*}{22} & 556748 & \multirow{3}{*}{556454} & \multirow{3}{*}{22.21} & \multirow{3}{*}{100.98} \\
\hline & & & & 556740 & & & \\
\hline & & & & 555876 & & & \\
\hline
\end{tabular}

${ }^{1}$ Mean area of $n=3$.

\begin{tabular}{|c|c|c|c|c|c|c|c|}
\hline $\begin{array}{l}\text { Level of } \\
\text { recovery }\end{array}$ & $\begin{array}{c}\text { Sample } \\
\text { Conc. } \\
(\mu \mathrm{g} / \mathrm{mL})\end{array}$ & $\begin{array}{c}\text { Conc. of Std } \\
\text { added }(\mu \mathrm{g} / \mathrm{mL})\end{array}$ & $\begin{array}{c}\text { Total } \\
\text { Conc. } \\
(\mu \mathrm{g} / \mathrm{mL})\end{array}$ & $\begin{array}{l}\text { Peak } \\
\text { Area }\end{array}$ & $\begin{array}{c}\text { Mean Peak } \\
\text { Area }^{1}\end{array}$ & $\begin{array}{c}\text { Amt } \\
\text { Recovered } \\
(\mu \mathrm{g} / \mathbf{m L})\end{array}$ & $\begin{array}{c}\% \\
\text { Recovery }\end{array}$ \\
\hline \multirow{3}{*}{$80 \%$} & \multirow{3}{*}{20} & \multirow{3}{*}{16} & \multirow{3}{*}{36} & 1854992 & \multirow{3}{*}{1830516} & \multirow{3}{*}{35.86} & \multirow{3}{*}{99.61} \\
\hline & & & & 1822824 & & & \\
\hline & & & & 1813732 & & & \\
\hline \multirow{3}{*}{$100 \%$} & \multirow{3}{*}{20} & \multirow{3}{*}{20} & \multirow{3}{*}{40} & 2097835 & \multirow{3}{*}{2085420} & \multirow{3}{*}{39.79} & \multirow{3}{*}{99.48} \\
\hline & & & & 2072219 & & & \\
\hline & & & & 2086205 & & & \\
\hline \multirow{3}{*}{$120 \%$} & \multirow{3}{*}{20} & \multirow{3}{*}{22} & \multirow{3}{*}{44} & 2243201 & \multirow{3}{*}{2254911} & \multirow{3}{*}{44.07} & \multirow{3}{*}{100.15} \\
\hline & & & & 2280277 & & & \\
\hline & & & & 2241254 & & & \\
\hline
\end{tabular}

${ }^{1}$ Mean area of $n=3$.

\subsubsection{6. $L O D$ and $L O Q$.}

The LOD and LOQ of the drugs were calculated using the following equation.

$\mathrm{LOD}=3.3 \sigma / \mathrm{S}$

$\mathrm{LOQ}=10 \sigma / \mathrm{S}$

where, $\sigma=$ standard deviation of the response, $\mathrm{S}=$ slope of the calibration curve.

\subsubsection{Robustness.}

The robustness of the developed method was checked by varying flow rates $( \pm 0.1 \mathrm{~mL} / \mathrm{min})$ and wavelength $( \pm 2 \mathrm{~nm})$. The results show that $\%$ RSD values are less than $2 \%$

\subsubsection{Analysis of developed formulation.}

The results of the assay were found to be within of label claim for formulations containing SAXA and DAPA, as shown in Table 9. 
Table 9. Assay data for SAXA and DAPA $(n=3)$.

\begin{tabular}{|c|c|c|c|}
\hline Drug & Label Claim (mg) & $\begin{array}{c}\text { Sample Conc. } \\
(\mu \mathrm{g} / \mathrm{mL})\end{array}$ & Peak Area \\
\hline \multirow[t]{3}{*}{ SAXA } & \multirow[t]{3}{*}{5} & \multirow[t]{3}{*}{16} & 400980 \\
\hline & & & 405403 \\
\hline & & & 406978 \\
\hline \multicolumn{3}{|c|}{$\%$ Assay \pm SD } & $101.02 \pm 3109$ \\
\hline \multicolumn{3}{|c|}{$\%$ RSD } & 0.76 \\
\hline \multirow[t]{3}{*}{ DAPA } & \multirow[t]{3}{*}{10} & \multirow[t]{3}{*}{32} & 1705610 \\
\hline & & & 1701686 \\
\hline & & & 1711731 \\
\hline \multicolumn{3}{|c|}{$\%$ Assay \pm SD } & $101.45 \pm 5062$ \\
\hline \multicolumn{3}{|c|}{ \%RSD } & 0.29 \\
\hline
\end{tabular}

\subsection{Discussion.}

In the development of the RP-HPLC method for estimating SAXA and DAPA in tablet formulation, it was found that the mobile phase composition of phosphate buffer and acetonitrile $(55: 45)$ was more appropriate for the simultaneous estimation of both the drugs, and the volume of acetonitrile resulted in a major change in retention time. These optimal conditions were achieved baseline separation of both drugs with a reasonable resolution and run time of less than $5 \mathrm{~min}$. The HPLC process has been approved according to Q2(R1) of the ICH Guidelines. The percentage of assay results for combination drugs is found to be within approval requirements (98-102 percent), result summary shown in Table 9.

UV method was based on the measurement of absorbance of Saxagliptin Hydrochloride and Dapagliflozin in methanol at $210 \mathrm{~nm}$ and $224 \mathrm{~nm}$, respectively. The linearity range was selected 6-22 $\mu \mathrm{g} / \mathrm{mL}$ and 12-44 $\mu \mathrm{g} / \mathrm{mL}$ for Saxagliptin Hydrochloride and Dapagliflozin, respectively. The validation parameters were performed according to the ICH guidelines Q2(R1). The precision results, expressed by intra-day and inter-day for both the drugs, were $\%$ $\mathrm{RSD}<2 \%$.

\section{Conclusions}

This research involves systematically developing a simple, fast, accurate, and costeffective UV spectrophotometric method for the simultaneous estimation of SAXA and DAPA. Better percentage recoveries and proper validation showed the appropriateness and efficiency of the proposed analytical procedures. Consequently, this approach can be implemented successfully for the routine consists of dosage form analysis comprising SAXA and DAPA. The RP-HPLC method optimized the resolution as a response in a relatively short time (5 min) between SAXA and DAPA. All system suitability parameters are observed in optimal condition, and it was found with the range for SAXA and DAPA estimation. In addition, the validation analysis helped identify the best conditions by verifying that the approach was selective, specific, accurate, linear, precise, and robust. The percentage assay values for formulations research were found to be between $98-102 \%$. The methods developed have been validated in accordance with ICH Q2 (R1) guidelines. In conclusion, simple, selective, sensitive, and accurate UV Spectroscopic and RP-HPLC methods have been developed and validated in agreement with ICH guidelines Q2 (R1) for the routine quality of the dosage form analyzes containing SAXA and DAPA. This method developed satisfies the guidelines of ICH Q2 (R1) and is appropriate for regulatory submission under regulatory flexibility. 


\section{Funding}

This research received no external funding.

\section{Acknowledgments}

We are grateful to Ramanbhai Patel College of Pharmacy, and Charotar University of Science and Technology, Charusat, for providing the requisite research infrastructure and facilities. We are also thankful to CTX Lifesciences (Surat) and Zydus Healthcare (Ahmedabad), who have provided a gratis sample of Saxagliptin Hydrochloride and Dapagliflozin, respectively.

\section{Conflicts of Interest}

The authors declare no conflict of interest.

\section{References}

1. Kusunoki, M.; Natsume, Y.; Miyata, T.; Tsutsumi, K.; Oshida, Y. Effects of concomitant administration of a dipeptidyl peptidase-4 inhibitor in Japanese patients with type 2 diabetes showing relatively good glycemic control under treatment with a sodium glucose co-transporter 2 inhibitor. Drug Res. 2018, 68, 704-709, https://doi.org/10.1055/a-0585-0145

2. Chilton, R.J. Effects of sodium-glucose cotransporter-2 inhibitors on the cardiovascular and renal complications of type 2 diabetes. Diabetes, Obesity and Metabolism 2020, 22, 16-29, https://doi.org/10.1111/dom.13854

3. Heerspink, H.J.L.; Kosiborod, M.; Inzucchi, S.E.; Cherney, D.Z.I. Renoprotective effects of sodium-glucose cotransporter-2 inhibitors. Kidney Int. 2018, 94, 26-39, https://doi.org/10.1016/j.kint.2017.12.027.

4. Prajapati, P.R.; Rathod, D.N.; Modi, V.S.; Basuri, T. Chemometrics and its Applications in UV Spectrophotometry. International Journal of Pharmaceutical Chemistry and Analysis 2016, 3, 43-48. https://doi.org/10.5958/2394-2797.2016.00005.8.

5. Lotfy, H.M.; Mohamed, D.; Elshahed, M.S. Novel univariate spectrophotometric determination of the recently released solid dosage form comprising dapagliflozin and saxagliptin via factorized response spectra: Assessment of the average content and dosage unit uniformity of tablets. Spectrochimica Acta Part A: Molecular and Biomolecular Spectroscopy 2019, 222, 117120, https://doi.org/10.1016/j.saa.2019.05.025.

6. Mante, G.V.; Gupta, K.R.; Hemke, A.T. Estimation of dapagliflozin from its tablet formulation by UVspectrophotometry. Pharm Methods 2017, 8, 102-107, https://doi.org/10.5530/phm.2017.8.16.

7. Hassib, S.T.; Taha, E.A.; Elkady, E.F.; Barakat, G.H. Development and Validation of Spectrophotometric Methods for the Determination of Canagliflozin or Gliclazide and Metformin in the Presence of Metformin Impurity (1-Cyanoguanidine). J. AOAC Int. 2019, 102, 1112-1124, https://doi.org/10.5740/jaoacint.18-0234.

8. Merey, H.A.; Ramadan, N.K.; Diab, S.S.; Moustafa, A.A. Chromatographic methods for the simultaneous determination of binary mixture of Saxagliptin $\mathrm{HCl}$ and Metformin $\mathrm{HCl}$. Bulletin of Faculty of Pharmacy, Cairo University 2017, 55, 311-317, https://doi.org/10.1016/j.bfopcu.2017.04.002.

9. Donepudi, S.; Achanta, S. Simultaneous Estimation of Saxagliptin and Dapagliflozin in Human Plasma by Validated High Performance Liquid Chromatography-Ultraviolet Method. Turkish Journal of Pharmaceutical Sciences 2019, 16, 227, https://doi.org/10.4274/tjps.galenos.2018.46547.

10. Kant, R.; Bodla, R.B.; Kapoor, G.; Bhutani, R. Optimization of a single HPLC-PDA method for quantifying Metformin, Gliclazide, Pioglitazone, Dapagliflozin, Empagliflozin, Saxagliptin, Linagliptin and Teneligliptin using central composite design. Bioorg. Chem. 2019, 91, 103111, https://doi.org/10.1016/j.bioorg.2019.103111.

11. Gundala, A.; Prasad, K.; Koganti, B. Application of quality by design approach in RP-HPLC method development for simultaneous estimation of saxagliptin and dapagliflozin in tablet dosage form. Brazilian Journal of Pharmaceutical Sciences 2019, 55, https://doi.org/10.1590/s2175-97902019000218129.

12. Maher, H.M.; Abdelrahman, A.E.; Alzoman, N.Z.; Aljohar, H.I. Stability-indicating capillary electrophoresis method for the simultaneous determination of metformin hydrochloride, saxagliptin hydrochloride, and 
dapagliflozin in pharmaceutical tablets. J. Liq. Chromatogr. Rel. Technol. 2019, 42, 161-171, https://doi.org/10.1080/10826076.2019.1590208.

13. Ganorkar, S.B.; Sharma, S.S.; Patil, M.R.; Bobade, P.S.; Dhote, A.M.; Shirkhedkar, A.A. Pharmaceutical Analytical Profile for Novel SGL-2 Inhibitor: Dapagliflozin. Crit. Rev. Anal. Chem. 2020, 1-13, https://doi.org/10.1080/10408347.2020.1777524.

14. Prasad, P.B.N.; Satyanaryana, K.; Krishnamohan, G. Development and Validation of a Method for Simultaneous Determination of Metformin and Saxagliptin in a Formulation by RP-HPLC. American journal of analytical chemistry 2015, 6, 841, https://doi.org/10.4236/ajac.2015.611080.

15. Gumieniczek, A.; Berecka, A. Analytical tools for determination of new oral antidiabetic drugs, glitazones, gliptins, gliflozins and glinides, in bulk materials, pharmaceuticals and biological samples. Open Chemistry 2016, 14, 215-242, https://doi.org/10.1515/chem-2016-0023.

16. Hassib, S.T.; Taha, E.A.; Elkady, E.F.; Barakat, G.H. Validated Liquid Chromatographic Method for the Determination of (Canagliflozin, Dapagliflozin or Empagliflozin) and Metformin in the Presence of (1Cyanoguanidine). J. Chromatogr. Sci. 2019, 57, 697-707, https://doi.org/10.1093/chromsci/bmz042.

17. Peng, Y.; Chang, Q.; Yang, N.; Gu, S.; Zhou, Y.; Yin, L.; Aa, J.; Wang, G.; Sun, J. Quantitative determination of metformin, saxagliptin and 5-hydroxy saxagliptin simultaneously by hydrophilic interaction liquid chromatography - electrospray ionization mass spectrometry and its application to a bioequivalence study with a single-pill combination in human. J. Chromatogr. B 2018, 1081-1082, 109-117, https://doi.org/10.1016/j.jchromb.2018.02.007.

18. Surendran, S.; Paul, D.; Pokharkar, S.; Deshpande, A.; Giri, S.; Satheeshkumar, N. A LC-MS/MS method for simultaneous estimation of a novel anti-diabetic combination of saxagliptin and dapagliflozin using a polarity switch approach: application to in vivo rat pharmacokinetic study. Analytical Methods 2019, 11, 219-226, https://doi.org/10.1039/C8AY02087F.

19. Wattamwar, T.; Mungantiwar, A.; Halde, S.; Pandita, N. Development of simultaneous determination of empagliflozin and metformin in human plasma using liquid chromatography-mass spectrometry and application to pharmacokinetics. Eur. J. Mass Spectrom. 2020, 26, 117-130, https://doi.org/10.1177/1469066719879297

20. Group, I.C.H.E.W. ICH Q2 (R1) Validation of Analytical Procedures: Text and Methodology. Geneva, Switzerland $\mathbf{2 0 0 5}$.

21. Desai, P.; Mori, K.; Patel, M. Development and Validation of UV-Visible Spectrophotometric Method for Simultaneous Estimation of Momentasone Furoate, Hydroquinone and Tretinoin from their Pharmaceutical Dosage Form. international journal of pharmaceutical science research and Review 2013, 21, 296-300.

22. Patel, M.; Patel, H. Development and Validation of UV Spectrophotometric Method for Simultaneous estimation of Terbinafine hydrochloride and Mometasone furoate in Combined Dosage Form. Asian Journal of research in chemistry 2013, 6, 29-34.

23. Patel, D.; Patel, M.; Patel, K. Simultaneous RP-HPLC estimation of moxifloxacin hydrochloride and ketorolac tromethamine in ophthalmic dosage forms. Asian Journal of Research in Chemistry 2012, 5, 697-700. 